\title{
MAXIMUM PHONATION TIMES OF ELDERLY WOMAN WITH AND WITHOUT UPPER DENTAL PROSTHESIS
}

\author{
Tempos máximos de fonação de idosas \\ com e sem prótese dentária superior
}

\author{
Carla Aparecida Cielo (1), Vanessa Veis Ribeiro (2), Carla Franco Hoffmann (2), \\ Ariane de Macedo Gomes ${ }^{(2)}$, Famiely Colman Machado de Machado ${ }^{(3)}$
}

\begin{abstract}
Purpose: to characterize and compare maximum phonation times in elderly women that wear upper dental prosthesis and elderly women with upper natural teeth. Methods: 31 elderly women were divided into an experimental group - 19 ladies who wore upper dental prosthesis, average age of 71.21 years and a control group - 12 women who did not wear dental prosthesis, mean age of 69.83 years. Maximum phonation time values of fricatives /s/ and / $/$ / and vowels /a/, /i/ and / $/$ / were analyzed through the parametric Paired Student's t-test. Results: the averages for vowels /a/, /i/ and / $/ \mathrm{l} /$ and fricatives /s/ and /z/ were within the expected ranges in the control group (14.86s; 15.40s; 15.85s; 14.09s and $14.30 \mathrm{~s}$, respectively) and below the expected range in the experimental group (10.84s; $10.53 \mathrm{~s} ; 10.74 \mathrm{~s}$; $10.25 \mathrm{~s}$ and $10.95 \mathrm{~s}$ respectively). There was no statistical difference between the elderly women of the two groups for maximum phonation time of the vowels; which was not the case for the fricatives. Conclusion: the group of elderly women with natural teeth reached the longest phonation time for vowels and fricatives that is minimally expected from female adults while the group of elderly women with full upper dental prosthesis had lower values than expected. Contrary to expectations, there was no difference in maximum phonation time values of fricatives when the groups were compared, but the maximum phonation time of all analyzed vowels was lower in the group that wears prosthesis. The results show the influence of wearing dental prosthesis on the results of maximum phonation time of elderly women.
\end{abstract}

KEYWORDS: Phonation; Aged; Dental Prosthesis; Voice

\section{INTRODUCTION}

The voice is an instrument capable of conveying feelings and emotions; it changes according to age, physical characteristics, location, environment, life history, among others factors. Aging results in a process that can affect the smooth operation of

\footnotetext{
(1) Curso de Graduação em Fonoaudiologia e Programa de Pós-Graduação em Distúrbios da Comunicação Humana, Universidade Federal de Santa Maria/UFSM, Santa Maria, RS, Brasil.

(2) Universidade Federal de Santa Maria/UFSM, Santa Maria, RS, Brasil.

(3) Universidade Federal da Bahia/UFBA, Salvador, BA, Brasil. Research grant agency: CAPES (Coordination for Improvement of Higher Education Personnel)

Conflict of interest: non-existent
}

speech organs, which are the structures responsible for speech production ${ }^{1-3}$. The aging process is progressive and degenerative; it is characterized physiologically by weakened defense mechanisms and loss of functional reserves, and physically, by reduced capacity for environmental adaptation and reduced speed of performance of daily activities ${ }^{3-5}$.

The human larynx also suffers the consequences of aging and begins to assume particular characteristics. This set of changes is called "presbylarynx"1,3-7. Voice production assumes specific features, i.e., slower pace of speech; pneumophonoarticulatory incoordination; reduction of maximum phonation time (MPT), maximum phonation range, vocal stability, airflow, loudness and sound pressure airflow; there is also increased acoustic measure of jitter, which gives the impression of tremor ${ }^{3,4,7-12}$. 
Furthermore, voice quality can be characterized by asthenia, crackle, breathiness, strain, hoarseness and also vocal fatigue, which are typical of presbyphonia ${ }^{3,9-11,13}$.

As people grow older, they may have diseases associated with voice changes, e.g., changes in the stomatognathic system with hypotension of lips, tongue and cheeks; absence of teeth, etc.,5,11.

The loss of teeth and the use of poorly fitting dental prostheses may cause phonation difficulties in the elderly as well, and it may also negatively influence the orofacial proprioception and joint movement, aggravated by hyposalivation, reduction of orofacial muscle tension and restriction of temporomandibular joint movement ${ }^{14}$. These factors may cause the elderly to systematically alter the position of the articulation, especially during the production of fricative sounds ${ }^{15,16}$, known as sibilants, whereby the main sound source is turbulence produced when the air stream created by the vocal tract constriction meets the upper teeth ${ }^{17,18}$. Therefore, the loss of teeth and the use of poorly fitting dental prostheses interfere mainly in the production of this class of sounds.

According to the literature, the importance of oral health is not acknowledged by the elderly. This is confirmed when full tooth loss (edentulism) is seen as a normal and natural phenomenon that occurs with aging rather than the result of lack of health preventive policies aimed at the adult population for maintenance of teeth until advanced ages ${ }^{14,16,19}$. This long-standing dental paradigm of edentulism has been improving over the years as people are increasingly conserving their natural teeth, and this is directly associated with the socioeconomic and cultural conditions of the population ${ }^{19-21}$.

In developed countries, people had 7.4 teeth on average in 1960, and this number went up to about 20 teeth in $2000^{21}$. However, in countries like Brazil, most elderly people nowadays, especially those who had access to the public health system, have had essentially curative dental treatment, where the practice of tooth extraction was the main therapeutic procedure, which is why most elderly people wear prostheses on both dental arches, mainly in the upper $\operatorname{arch}^{20,22,23}$.

There are no studies that have evaluated the influence of using upper dental prosthesis on the MPT of the elderly. Such an approach can help speech therapists to evaluate this population further, establishing a reliable therapeutic process that may ease communicative losses due not only to aging, but also to the use of dental prostheses, thus allowing greater quality and enjoyment of life for the elderly.
Based on the context above-mentioned, the aim of this work is to characterize and compare MPT of users of upper dental prostheses and women with natural upper teeth.

\section{METHODS}

This is an analytical quantitative and observational retrospective cross-sectional study on data of patients treated in the voice department of a clinical school of speech therapy. It was previously approved by the Research Ethics Committee (23081.016945/2010-76) of the Federal University of Santa Maria. All patients had previously signed the informed consent form, authorizing the use of the assessment data in scientific research as long as secrecy about their identity was maintained.

The target population consisted of elderly women who sought the voice department of a clinical school of speech therapy, from January 1998 to December 2013. The participants were divided into two groups: Experimental Group (EG): ladies who wore upper dental prosthesis; Control Group (CG): ladies who did not wear dental prosthesis. The selection of the sample was based on specific inclusion and exclusion criteria that were established for each group.

For the EG, the inclusion criterion was the use of full upper dental prosthesis; for the CG, the criterion was the presence of permanent teeth in both arches, with or without dental flaws that did not undermine the production of the phonemes targeted for analysis. For both groups, the following inclusion criteria were taken into consideration: female patients, because there is a greater number of studies involving women and more data available on the database, possibly because women seek health care services more often ${ }^{24-28}$; old age group (65-79 years) (MeSH); records of MPT production of vowels /a/, /i/ and /u/ and fricatives /s/ and /z/. The exclusion criteria for both groups were: incomplete data, males, people aged under 65 and over 79 years old, laryngeal disorders other than presbylarynx, record of neurological or lung diseases, smoking, alcohol consumption, occurrence of stomach or allergy symptoms on rating. There were 68 subjects within the target age range; however, 12 subjects were excluded because of incomplete data; 18 of them were male, two they had lung diseases and five had neurological diseases.

Thus, the sample consisted of 31 elderly women with a mean age of 70.29 years, who were divided into: EG - 19 ladies who wore upper dental prosthesis, mean age 71.21 years; CG - 12 ladies who did not wear dental prosthesis, mean age of 69.83 years. 
Data on criteria for inclusion and exclusion, as well as on the values of MPT of the fricatives /s/ and $\mid z /$, and the vowels /a/, /i/ and /u/ were collected from the Database, tabulated and statistically analyzed using the parametric Paired Student's T-test with a significance level of $5 \%$.

\section{RESULTS}

Table 1 shows the descriptive analysis of MPT for vowels and fricatives in both groups.

Table 2 shows a significant difference between groups for MPT of the vowels.

Table 1 - Descriptive analysis of maximum phonation times of vowels and fricatives of the control group and the experimental group

\begin{tabular}{ccccc}
\hline & Group & Mean & Median & Standard Deviation \\
\hline \multirow{2}{*}{ MPT /a/ } & CG & 14.86 & 15.00 & 5.63 \\
& EG & 10.84 & 11.00 & 4.88 \\
$\mathrm{MPT} / \mathrm{i} /$ & CG & 15.40 & 15.39 & 6.34 \\
& EG & 10.53 & 10.19 & 4.55 \\
$\mathrm{MPT} / \mathrm{u} /$ & $\mathrm{CG}$ & 15.85 & 15.60 & 5.23 \\
& EG & 10.74 & 10.13 & 4.02 \\
$\mathrm{MPT} / \mathrm{s} /$ & $\mathrm{CG}$ & 14.09 & 12.16 & 5.43 \\
& EG & 10.25 & 9.00 & 4.56 \\
$\mathrm{MPT} / \mathrm{z} /$ & $\mathrm{CG}$ & 14.30 & 14.00 & 5.05 \\
& EG & 10.95 & 10.00 & 4.75 \\
\hline
\end{tabular}

Descriptive analysis of variables

Caption: $E G=e x p e r i m e n t a l$ group; $C G=$ control group; $M P T=$ maximum phonation time.

Table 2 - Comparison of maximum phonation time between control group and experimental group

\begin{tabular}{lccc}
\hline MPT & Groups & Mean & Value for $\mathbf{p}$ \\
\hline \multirow{2}{*}{$/ \mathrm{a} /$} & EG & 14.86 & $0.043^{*}$ \\
& CG & 10.84 & $0.022^{*}$ \\
li/ & EG & 15.40 & \\
& CG & 10.53 & $0.004^{*}$ \\
lu/ & EG & 15.85 & \\
& CG & 10.74 & 0.051 \\
/s/ & EG & 14.09 & \\
& CG & 10.25 & 0.064 \\
lz/ & EG & 14.30 & \\
\hline
\end{tabular}

* Statistically significant results $(p \leq 0.05)$ - Paired Student's t-test.

Caption: MPT = maximum phonation time; $E G$ = experimental group; $C G$ = control group.

\section{DISCUSSION}

The evaluation of MPT is a test applied to verify glottal efficiency objectively ${ }^{18,29}$. MPT is one of the measures used in speech therapy clinics as a means of diagnosing or monitoring the clinical evolution of patients ${ }^{18,25-29}$. However, there are still few studies published on the MPT of elderly people, particularly on the normal parameters for this population
Research on MPT for the elderly uses as a measure of normality, for comparison, the TMF values expected for adults ${ }^{3,13,15}$ or the values found in similar studies ${ }^{4,13}$. However, the comparison with the MPT of adults may be questioned, because there are factors associated with the aging of the larynx and typical characteristics of the phonation of the elderly, which usually result in lower MPT measures $4,7,9,11$. 
The MPT values of vowels /a/, /i/ and / $/ 4$ of adult women as found in the literature range between 14.04 and $26.96 \mathrm{~s}^{4,29,30}$ and the MPT of fricatives /s/ and $/ z /$ range between 14.04 and $34.17 \mathrm{~s}^{13,18,29-31}$. In this study, all MPT values for the CG, both for vowels and fricatives, achieved the minimum time expected for adult women,14.04 $\mathrm{S}^{4,29,30}$, while for the elderly who wore upper dental prosthesis, MPT values were below the minimum value expected $(E G)^{18,32}$ (Table 1 ). These findings corroborate the fact that aging results in decreased MPT ${ }^{4,7,9,11}$ and that the use of upper dental prosthesis can interfere negatively in maintenance of vocal emission ${ }^{33}$. In addition, they show that MPTs were higher for elderly women who did not wear dental prosthesis.

Comparing MPTs between the groups, the research hypothesis was that there would be reduction of MPTs of fricatives compared with those of vowels in the EG because of the use of upper dental prosthesis, which is difficult to control while producing speech sounds ${ }^{33}$. When fricatives are produced, airflow passes through a significant narrowing in the oral cavity, sufficient to produce air turbulence against the alveolar point of articulation $^{17,18}$. They are produced by friction of the air stream on the teeth and their MPT is expected to be lower than that of vowels, which do not have articulation point on the hard palate, teeth or alveoli, regions where the use of prosthesis may result in impaired proprioception.

However, MPT was significantly decreased in the EG for vowels only, but there were no differences in the MPT values of fricatives (Table 2). These results were totally unexpected because of the way fricatives are produced ${ }^{17,18}$ and also because vowels require greater lip movement, and the shape of the dental prosthesis tends to cause little impact on their production $^{34}$.

These results also contradict the decrease of MPT of fricatives compared with that of vowels in the elderly, as observed in another study that did not consider the use of dental prosthesis as a variable ${ }^{13}$. However, in a study ${ }^{35}$ that compared elderly people who wore full dental prostheses with those who had natural teeth, closed articulation was observed in the two groups, and it may interfere with the production of MPT of both vowels and fricatives. This type of articulation may compensate for the physiological aging process which results in decreased muscle tension of the articulators, which is also influenced by hyposalivation ${ }^{35}$.

Based on the findings in the elderly group, MPT values of fricatives seem more reliable when assessing MPT of elderly people who wear full dental prostheses as compared with MPT of values of vowels, which were significantly different between the groups analyzed; this may lead the evaluator to misinterpret the data of an elderly patient.

It should be noted that this research has not examined the length of use of upper dental prostheses, or the speech articulation of the elderly females. It is stated that the ability to control the prosthesis contributes to changes in oral functions and interferes with speech production ${ }^{33}$; thus, adaptation to the prosthesis is a factor to be considered in future studies, because the loss of teeth and poorly fitting dental prostheses create articulatory difficulties, worsened by decreased production of saliva and reduced orofacial muscle tone ${ }^{15}$. Research on vocal measures of elderly people who wear dental prosthesis are scarce and must be explored further, because the use of prostheses is common among the elderly $y^{20,22,23}$.

As a result of increased longevity and reduced mortality rate, about $20 \%$ of the population is currently facing the changes that occur in old age. This creates a demand for care in speech therapy clinics, which should be prepared for evaluation and rehabilitation of the elderly in order to improve their health and quality of life ${ }^{3,4}$.

Randomized studies should be conducted to examine the MPT of a larger sample of both male and female elderly patients.

\section{CONCLUSION}

The group of elderly women with natural teeth reached the minimum MPT values for vowels and fricatives expected for adult females, and the group of elderly women with full upper dental prosthesis had lower MPT values than expected. Contrary to expectations, the comparison of MPT for fricatives between groups showed no difference, but the MPT values of all analyzed vowels was lower in the group that wears prosthesis. The results show that MPT values were higher in the group of elderly women who did not wear dental prosthesis. 


\section{RESUMO}

Objetivo: caracterizar e comparar o tempo máximo de fonação de idosas usuárias de prótese dentária superior e de idosas com dentição superior natural. Métodos: 31 idosas que foram divididas em: grupo experimental - 19 senhoras que utilizavam prótese dentária superior, média de idade de 71,21 anos; grupo controle - 12 senhoras que não utilizavam prótese dentária, média de idade de 69,83 anos. Analisaram-se os valores dos tempos máximos de fonação das fricativas $/ \mathrm{s} / \mathrm{e} / \mathrm{z} /$, e das vogais la/, /i/ e /u/ por meio do teste paramétrico T-Student Pareado. Resultados: as médias das vogais /a/, /i/ e /u/ e das fricativas /s/ e /z/ estiveram dentro do esperado no grupo controle $(14,86 \mathrm{~s} ; 15,40 \mathrm{~s} ;$ $15,85 \mathrm{~s} ; 14,09 \mathrm{~s}$ e $14,30 \mathrm{~s}$, respectivamente) e abaixo no grupo experimental $(10,84 \mathrm{~s} ; 10,53 \mathrm{~s} ; 10,74 \mathrm{~s}$; $10,25 \mathrm{~s}$ e $10,95 \mathrm{~s}$, respectivamente). Houve diferença estatística entre as idosas dos dois grupos para o tempo máximo de fonação das vogais, o que não foi encontrado no das fricativas. Conclusão: o grupo de idosas com dentição natural atingiu o tempo máximo de fonação mínimo de vogais e de fricativas esperado para adultos do sexo feminino e o grupo de idosas com prótese dentária superior completa ficou abaixo do esperado. Ao contrário do esperado, a comparação do tempo máximo de fonação das fricativas entre os grupos não mostrou diferença, mas o tempo máximo de fonação de todas as vogais analisadas foi menor no grupo com prótese. Os resultados mostram a influência do uso de prótese dentária sobre os resultados de tempo máximo de fonação de idosas.

DESCRITORES: Fonação; Idoso; Prótese Dentária; Voz

\section{REFERENCES}

Rocha TF, Amaral FP, Hanayama EM. Extensão vocal de idosos coralistas e não coralistas. Rev CEFAC. 2007;9(2):248-54.

2. Gampel D, Karsch UM, Ferreira LP. Envelhecimento, voz e atividade física de professores e não professores. Rev Soc Bras Fonoaudiol. 2008;13(3):218-25.

3. Menezes LN, Vicente LCC. Envelhecimento vocal em idosos institucionalizados. Rev CEFAC. 2007;9(1):90-8.

4. Cerceau JSB, Alves CFT, Gama ACC. Análise acústica da voz de idosas. Rev CEFAC. 2009;11(1):142-9.

5. Penteado RZ, Penteado LAPB. Voz e saúde vocal de idosos coralistas. Rev CEFAC. 2010;12(2):191-8.

6. Benninger MS, Abitbol J. Voice: dysphonia and the aging voice. 3rd ed. In: American Academy of Otolaryngology Head and Neck Surgery Foundation. Geriatric Care Otolaryngology. Alexandria: AAO-HNSF; 2006. p. 67-81.

7. Gorham-Rowan MM, Laurens-Gore J. Acousticperceptual correlates of voice quality in elderly men and women. J Commun Disord. 2006;39(3):171-84.

8. Soyama CK, Espassatempo CDL, Gregio FN, Camargo ZA. Qualidade vocal na terceira idade: parâmetros acústicos de longo termo de vozes masculinas e femininas. Rev CEFAC. 2005;7(2):267-79.
9. Kendall K. Presbyphonia: a review. Curr Opin Otolaryngol Head Neck Surg. 2007;15(3):137-40.

10. Vasconcelos SV, Mello RJV, Silva HJ. Efeitos do envelhecimento e do fumo nas pregas vocais: uma revisão sistemática. ACTA ORL. 2009;27(1):9-14.

11. Oliveira G, Behlau M. Descrição da qualidade vocal de personagens idosos dos filmes de Hollywood. Rev CEFAC. 2010;12(3):483-9.

12. Prakup B. Acoustic measures of the voices of older singers and nonsingers. $\mathrm{J}$ Voice. 2012;26(3):341-50.

13. Fabron EMG, Sebastião LT, Oliveira GAG, Motonaga SM. Medidas da dinâmica respiratória em idosos participantes de grupos de terceira idade. Rev CEFAC. 2011;13(5):895-901.

14. Araújo PF, Silva EFA, Silva DD, Souza MLR. Qualidade de vida em adultos e idosos que procuraram a Faculdade de Odontologia de Piracicaba para confeccionar próteses totais. Rev Odontol UNESP. 2008;37(2):109-16.

15. Polido AM, Martins M, Hanayama EM. Percepção do envelhecimento vocal na terceira idade. Rev CEFAC. 2005;7(2):241-51.

16. Maruch AO, Ferreira EF, Vargas AMD, Pedroso MAG, Ribeiro MTF. Impacto da prótese dentária total removível na qualidade de vida de idosos em Grupos de convivência de Belo Horizonte- MG. Arq Odontol. 2009;45(2):73-80.

17. Aasland WA, Baum SR, McFarland DH. Eletropalatographic, accoustic, and perceptual data 
on adaptation to a palatal pertubation. J Acoust Soc Am. 2006;119(4):2372-81.

18. Cielo CA, Casarin MT. Sons fricativos surdos. Rev CEFAC. 2008;10(3):352-8.

19. Medeiros JJ, Rodrigues LV, Azevedo AC, Neto EAL, Machado LS, Valença AMG. Edentulismo, uso e necessidade de prótese e fatores associados em município do nordeste brasileiro. Pesq Bras Odontoped Clin Integr. 2012;12(4):573-8.

20. Barbato PR, Nagano HCM, Zanchet FN, Boing AF, Peres MA. Perdas dentárias e fatores sociais, demográficos e de serviços associados em adultos brasileiros: uma análise dos dados do Estudo Epidemiológico Nacional (Projeto SB Brasil 2002-2003). Cad Saúde Pública. 2007;23(8):1803-14.

21. Montenegro FLB, Marchini L, Brunetti RF. Aspectos importantes na prótese total para $3^{\text {a }}$ idade. In: Cunha VPP, Marchini L. Prótese total contemporânea em reabilitação oral. São Paulo: Editora Santos; 2007. p. 177-94.

22. Moimaz SAS, Saliba NA, Santos CLV. Análise do comportamento de um grupo de terceira idade portador de prótese total, antes e após programa de saúde bucal. Rev Fac Odontol. 2004;16(1):35-40.

23. Costa AM, Guimarães MCM, Pedrosa SF, Nóbrega OT, Bezerra ACB. Perfil da condição bucal de idosas do Distrito Federal. Ciênc Saúde Coletiva. 2010;15(4):2207-13.

24. Frazão P, Antunes JLF, Narvai PC. Perda dentária precoce em adultos de 35 a 44 anos de idade. Estado de São Paulo, Brasil, 1998. Rev Bras Epidemiol. 2003;6(1):49-57.

25. Finger LS, Cielo CA. Modificações vocais acústicas produzidas pela fonação reversa. Rev Soc Bras Fonoaudiol. 2009;14(1):15-21.
26. Finger LS, Cielo CA, Schwarz K. Medidas vocais acústicas de mulheres sem queixas de voz e com laringe normal. Braz J Otorrinolaryngol. 2009;75(3):432-40.

27. Roman-Niehues G, Cielo CA. Modificações vocais acústicas produzidas pelo som hiperagudo. Rev CEFAC. 2010;12(3):462-70.

28. D'avila $\mathrm{H}$, Cielo $\mathrm{CA}$, Siqueira MS. Som fricativo sonoro /z/: modificações vocais. Rev CEFAC. 2010;12(6):915-24.

29. Beber BC, Cielo CA, Siqueira MA. Lesões de borda de pregas vocais e tempos máximos de fonação. Rev CEFAC. 2009;11(1):134-41.

30. Colton RH, Casper JK, Leonard R. Compreendendo os problemas de voz: uma perspectiva fisiológica ao diagnóstico e ao tratamento. 1st ed. Rio de Janeiro: Revinter; 2010.

31. Gelfer MP, Pazera JF. Maximum duration of sustained $/ \mathrm{s} /$ and $/ \mathrm{z} /$ and the $\mathrm{s} / \mathrm{z}$ ratio with controlled intensity. J Voice. 2006;20(3):369-79.

32. Kurtz LO, Cielo CA. Tempos máximos de fonação de vogais em mulheres adultas com nódulos vocais. Pró-Fono R Atual Cient. 2010;22(4):451-4.

33. Scott BJ, Hunter RV. Creating complete dentures that are stable in function. Dent Update. 2008;35(4):259-62.

34. Heydecke G, McFarland DH, Feine JS, Lund JP. Speech with maxillary implant prostheses: ratings of articulation. J Dent Res. 2004;83(3):236-40.

35. Rodrigues LCB, Pegoraro LF, Brasolotto AG, Berretin-Felix G, Genaro KF. A fala nas diferentes modalidades de reabilitação oral protética em idosos. Pró-Fono R Atual Cient. 2010;22(2):151-6.

Received on: January 13, 2014

Accepted on: June 30, 2014

Mailing address:

Carla Aparecida Cielo

UFSM - Av. Roraima no 1000 -

Cidade Universitária - Bairro Camobi

Prédio $26-4^{\circ}$ andar -

Departamento de Fonoaudiologia

Santa Maria - RS - Brasil

CEP: 97105-900

E-mail: cieloca@yahoo.com.br 